\title{
sciendo
}

Current Issues in Pharmacy and Medical Sciences

Formerly ANNALES UNIVERSITATIS MARIAE CURIE-SKLODOWSKA, SECTIO DDD, PHARMACIA

\section{Non-carious lesions in patients treated for functional temporomandibular disorders}

\author{
Justyna Oleszek-Listopad ${ }^{1}{ }^{\circledR}, J_{\text {Joanna }}$ Rosiak $^{2}{ }^{\circledR}$, Jolanta Szymanska $^{2 *}$
}

${ }^{1}$ Department of Prosthetics, Medical University of Lublin, Poland

${ }^{2}$ Department of Integrated Paediatric Dentistry, Medical University of Lublin, 58 Lubartowska, 20-094 Lublin, Poland

\section{ARTICLE INFO}

Received 08 January 2019

Accepted 14 February 2019

\section{Keywords:}

non-carious lesions, attrition,

abrasion,

temporomanidibular

disorders.

\begin{abstract}
Introduction. Numerous clinical symptoms found in patients with temporomandibular disorders include non-carious lesions, such as V-shaped lesions, wear facets, enamel cracks, and impressions on the tongue or changes in the buccal mucosa. In addition, loosening and dislocation of teeth may occur.

Aim. The aim of the study was to obtain a clinical assessment of the prevalence and severity of non-carious lesions of dental hard tissues (attrition and abrasion) in patients treated for functional temporomandibular disorders.

Material and methods. The clinical research was performed among 45 patients of both genders, aged 16-38 years, treated at the Department of Functional Masticatory Disorders at the Medical University of Lublin, Poland. The study group consisted of 30 patients with diagnosed temporomandibular disorders. The control group included 15 individuals with no diagnosed temporomandibular disorders. The control group was selected using the method of analogues (considering age, gender and dental status). The examinations were performed before the treatment and twelve weeks after its beginning.

Results. The study found significantly higher values of the prevalence and severity of attrition in the patients group, in comparison with the control group $(\mathrm{p}<0.05)$. In the case of abrasion, higher values of the studied variables of prevalence and severity of lesions in the patients, compared to controls, were also found, but the differences were not statistically significant ( $\mathrm{p}>0.05)$.

Conclusions. Attrition occurs more frequently and is more severe in patients with diagnosed temporomandibular disorders than in those without such diagnosis. However, no significant differences have been found in the prevalence and severity of abrasion in both groups.
\end{abstract}

\section{INTRODUCTION}

A dysfunction in the motor system of the masticatory organ is, at present, one of the main reasons for patients consulting their dentists. The intraoral examination of patients with temporomandibular disorders (TMD) showed, among numerous clinical symptoms, the presence of non-carious lesions in the dentition, including $\mathrm{V}$-shaped lesions, wear facets, enamel cracks, as well as impressions on the tongue and changes in the buccal mucosa. In addition, loosening and dislocation of teeth may occur $[1,2]$.

One of the basic factors contributing to temporomandibular disorders is civilization stress. The many ways

\footnotetext{
${ }^{\star}$ Corresponding author

e-mail: szymanska.lublin@gmail.com
}

of coping with stress-related emotions include occlusal and non-occlusal parafunctional activities. Parafunctions persisting for a long time lead to the damage of tissues and organs in the stomatognathic system [3].

Non-carious lesions characteristic for patients with diagnosed temporomandibular disorders include, among others, attrition and abrasion. Attrition is defined as a gradual wear of dental hard tissues caused by pathological or physiological tooth-to-tooth contact. Pathological wear is a symptom of dysfunctions in the stomatognathic system resulting from abnormal position and/or function of teeth, and may affect individual teeth or their groups. Abrasion is a type of tooth wear caused by hard objects and/or abrasive materials. Abrasive lesions are characterized by a smooth, glistening and hard surface [4]. Pathological wear usually 
progresses quicker in men than in women. At the advanced stage, the loss of dental hard tissues due to abrasion, attrition or erosion may lead to a considerable decrease in the occlusal height. This may reach a point wherein treatment requires an interdisciplinary approach $[5,6]$.

\section{AIM}

The aim of the study was to derive a clinical assessment of the prevalence and severity of non-carious lesions of dental hard tissues: attrition and abrasion in patients treated for functional temporomandibular disorders.

\section{MATERIAL AND METHODS}

The clinical research was performed among 45 patients of both genders, aged 16-38 years, who were directed to the Department of Functional Masticatory Disorders at the Medical University of Lublin for treatment of painful disorders in the temporomandibular joint (TMJ). The patients that participated in the study were generally healthy and did not receive pharmacological treatment, including antibiotic and corticosteroid therapy, for at least 3 weeks before the examination. All the patients were informed about the nature of the study and expressed their written consent to the clinical examination.

The study design was approved by the Bioethics Board at the Medical University of Lublin, Poland (decision no. KE-0254/38/2016).

The following groups were designed: The study group included 30 patients with a diagnosed dysfunction of the temporomanidbular disorders, the control group consisted of 15 patients with no diagnosed temporomandibular disorders. The controls were selected according to age, gender and dental status, using the method of analogues. All the studied individuals in both groups had full permanent dentition. The examination was conducted twice: at the beginning of the study (examination I) and twelve weeks after its beginning (examination II). The research concerning attrition and abrasion was an element of a more comprehensive project that included a 12 -week observation period. The examined population consisted of women at $77.78 \%$ of the total and men at $22.22 \%$ of the total.

In examinations I and II, the status of the permanent teeth, including the prevalence and severity of non-carious lesions: abrasion and attrition, was assessed in the studied patients. No deciduous teeth were found during the examinations. The prevalence of attrition/abrasion was based on the detection of the presence or absence of attrition/abrasion. In the case of attrition, the chewing surfaces of posterior teeth, palatal surfaces of upper incisors, and labial surfaces of lower incisors were studied, while in the case of abrasion, the examination covered the labial surfaces of anterior teeth and the buccal surfaces of posterior teeth. The values of the prevalence of attrition/abrasion in each patient was calculated according to the following formulae:

attrition $(\%)=\frac{\text { number of teeth affected with attrition }}{\text { number of all examined teeth }} \times 100 \%$; abrasion $(\%)=\frac{\text { number of teeth affected with abrasion }}{\text { number of all examined teeth }} \times 100 \%$.
The evaluation of the severity of attrition and abrasion makes reference to the Martin scale tooth wear index. The index value ranges were interpreted as follows:

$0^{\circ}$ - no wear marks,

$1^{\circ}$ - enamel surface wear (cusps preserved),

$2^{\circ}$ - progressing wear of tooth cusps (areas of exposed dentine visible),

$3^{\circ}$ - complete enamel loss,

$4^{\circ}$ - crown worn to the cervical region,

$5^{\circ}$ - pulp exposed due to wear.

The values for each patient were calculated according to the following formulae:

$$
\begin{aligned}
& \text { attrition }=\frac{\text { the sum of Martin scale values }}{\text { number of teeth affected with attrition }} ; \\
& \text { abrasion }=\frac{\text { the sum of Martin scale values }}{\text { number of teeth affected with abrasion }}[7,8] .
\end{aligned}
$$

The results of clinical examinations were analyzed statistically.

\section{RESULTS}

\section{Control Group}

In controls, the non-carious lesions of attrition and abrasion were found as only individual cases. In a many case scenario, statistical analysis was impossible, and the observed differences were not statistically significant.

\section{Study Group \\ Attrition}

On the basis of the Wilcoxon matched-pairs rank test, no statistically significant differences between the percentage of teeth with attrition before the treatment and 12 weeks after its beginning were found in the study group $(p>0.05)$. However, differences of the variable values between examinations I and II were observed in 8 patients $(26.67 \%)$, while in 22 subjects $(73.33 \%)$, the values remained at the same level (Table 1).

On the basis of the Wilcoxon matched-pairs rank test, no statistically significant differences between the values of attrition severity before the treatment and 12 weeks after its beginning were found in the study group $(p>0.05)$. Differences of the variable values between examinations I and II were observed in 6 patients $(20.00 \%)$, while in 24 subjects $(80.00 \%)$, the values remained at the same level (Table 2$)$.

Table 1. Differences in the percentage of teeth with attrition in the study group between examinations I and II

\begin{tabular}{|l|c|c|c|c|}
\hline \multirow{2}{*}{ Pair of variables } & \multicolumn{4}{|c|}{ Wilcoxon matched-pairs rank test (study group.sta) } \\
\cline { 2 - 5 } & $\begin{array}{c}\text { Size } \\
\text { (valid results) }\end{array}$ & $\mathrm{T}$ & $\mathrm{Z}$ & $\mathrm{p}$ \\
\hline $\begin{array}{l}\text { attrition (no.) } \\
\text { \& attrition (\%) }\end{array}$ & 8 & 6.000000 & 1.680336 & 0.092893 \\
\hline
\end{tabular}

Table 2. Differences in the values of attrition severity in the study group between examinations I and II

\begin{tabular}{|l|c|c|c|c|}
\hline \multirow{2}{*}{ Pair of variables } & \multicolumn{4}{|c|}{ Wilcoxon matched-pairs rank test (study group.sta) } \\
\cline { 2 - 5 } & $\begin{array}{c}\text { Size } \\
\text { (valid results) }\end{array}$ & $\mathrm{T}$ & $\mathrm{Z}$ & $\mathrm{p}$ \\
\hline $\begin{array}{l}\text { attrition (no.) } \\
\text { \& attrition (\%) }\end{array}$ & 6 & 5.000000 & 1.153113 & 0.248865 \\
\hline
\end{tabular}

$\mathrm{T}-$ Wilcoxon test value for groups $\leq 25$

$Z$ - Wilcoxon test value for groups $>25$

p - significance level, probability 


\section{Abrasion}

Statistically significant differences were found in the percentage of teeth with abrasion before the treatment and 12 weeks after the beginning of the therapy $(\mathrm{p}<0.05)$. The differences were seen in 6 patients $(20.00 \%)$, while in $24(80.00 \%)$ subjects, the variable values remained at the same level (Table 3).

Table 3. Differences in the percentage of teeth with abrasion in the study group between examinations I and II

\begin{tabular}{|l|c|c|c|c|}
\hline \multirow{2}{*}{ Pair of variables } & \multicolumn{5}{|c|}{ Wilcoxon matched-pairs rank test (study group.sta) } \\
\cline { 2 - 5 } & $\begin{array}{c}\text { Size } \\
\text { (valid results) }\end{array}$ & $T$ & $Z$ & $p$ \\
\hline $\begin{array}{l}\text { abrasion (no.) } \\
\& \text { abrasion (\%) }\end{array}$ & 6 & 0.000000 & 2.201398 & 0.027709 \\
\hline
\end{tabular}

On the basis of the Wilcoxon matched-pairs rank test, no statistically significant differences between the values of abrasion severity before the treatment and 12 weeks after its beginning were found in the study group $(p>0.05)$. Differences of the variable values between examination I and II were detected in 4 patients $(13.33 \%)$, while in 26 subjects $(86.67 \%)$, the values remained at the same level (Table 4$)$.

Table 4. Differences in the values of abrasion severity in the study group between examinations I and II

\begin{tabular}{|l|c|c|c|c|}
\hline \multirow{2}{*}{ Pair of variables } & \multicolumn{4}{|c|}{ Wilcoxon matched-pairs rank test (study group.sta) } \\
\cline { 2 - 5 } & $\begin{array}{c}\text { Size } \\
\text { (valid results) }\end{array}$ & $\mathrm{T}$ & $\mathrm{Z}$ & $\mathrm{p}$ \\
\hline $\begin{array}{l}\text { abrasion (no.) } \\
\text { \& abrasion (\%) }\end{array}$ & 4 & 1.000000 & 1.460593 & 0.144128 \\
\hline
\end{tabular}

\section{Comparative analysis of the variables for the control and the study group}

\section{Atrrition}

Statistically significant higher values of the studied variables (percentage of affected teeth and severity of attrition) were found in the study group patients $(\mathrm{p}<0.05)$ (Table 5).

Table 5. Differences in the mean values of the percentage and severity of attrition in the control and study groups

\begin{tabular}{|l|c|c|}
\hline \multirow{2}{*}{\multicolumn{1}{c|}{ Studied variables }} & \multicolumn{2}{|c|}{ Statistical analysis (Mann-Whitney test) } \\
\cline { 2 - 3 } & $\mathrm{Z}$ & $\mathrm{p}$ \\
\hline attrition (\%) & -3.86 & 0.0001 \\
\hline attrition (Martin index) & 2.59 & 0.0100 \\
\hline
\end{tabular}

\section{Abrasion}

The analysis showed higher values of the studied variables (percentage and severity of abrasion) in the study group, but the differences were not statistically significant $(\mathrm{p}>0.05)$ (Table 6).

Table 6. Differences in the mean values of the percentage and severity of abrasion in the control and study groups

\begin{tabular}{|l|c|c|}
\hline \multirow{2}{*}{\multicolumn{2}{|c|}{ Studied variables }} & \multicolumn{2}{|c|}{ Statistical analysis (Mann-Whitney test) } \\
\cline { 2 - 3 } & $\mathrm{Z}$ & $\mathrm{p}$ \\
\hline abrasion (\%) & -1.48 & 0.1400 \\
\hline abrasion (Martin index) & -1.54 & 0.1200 \\
\hline
\end{tabular}

\section{DISCUSSION}

Patients with TMD show a higher masticatory efficiency, a greater number of tooth-to-tooth contact between opposing teeth when chewing and a prolonged chewing time during eating, in comparison to individuals without the dysfunction [9]. The present study found a higher prevalence and greater severity of attrition in the group with TMD, in comparison to patients without the dysfunction. Other authors also confirm the connection between temporomandibular disorders and pathological tooth wear [10-12]. Mickieviciute et al. observed the presence of pathological attrition involving both incisors and molars in TMD patients regardless of their age, as well as a more severe tooth wear than in the control group [11]. Yadav also confirmed more frequent attrition in patients with TMJD disfunction, and especially in those with pain on mouth opening and deviation of mandible while mouth opening [10].

In the present study, involving patients aged 16-38 years, the prevalence of non-carious lesions was low because of the young age of the studied subjects. It is known, however, that an increase in attrition prevalence with age, detected in the studies involving older age groups $[8,10,11,13]$, may be related to progressing physiological attrition [4].

In addition, in spite of the ambiguous and complex etiology of functional temporomandibular disorders, the usually listed risk factors include gender, exposure to stress, prolonged exposure to pain, as well as occlusal changes and parafunctions, especially bruxism, which may lead to pathological tooth wear [14]. This has also been confirmed by Jonsgar et al., who observed that patients with attrition more often reported the symptoms of bruxism and more often suffered from clinically confirmed nocturnal bruxism, as well as from muscle pain in the face on awakening [15]. Earlier research, however, did not find statistically significant correlation between bruxism as reported by patients and pain in the temporomandibular joint area on the one hand, and pathological tooth wear on the other [13].

Studies on the influence of internal and external factors on the development of non-carious lesions showed that malocclusions, parafunctions confirmed by clinical examination, and missing teeth occur almost twice more frequently in patients with non-carious lesions [16], which may lead to temporomandibular disorders.

It must also be stressed that patients with adaptive mechanisms such as tooth migration or wear, as well as periodontal lesions, develop symptomatic temporomandibular dysfunction syndrome [17]. Those patients subsequently consult a dentist to obtain specialist help, which may affect research results.

In more than half of the participants of the present study, the abrasion index was equal to zero.

Other research indicates that in subjects at a similar age (20-35 years), abrasion-type wear is the most common among the non-carious lesions (abfraction, erosion, abrasion) [16]. 


\section{CONCLUSIONS}

Within the limitations of this clinical study, it may be concluded that attrition occurs more frequently and is more severe in examined patients with diagnosed temporomandibular disorders than in those without such diagnosis. However, no significant differences have been found in the prevalence and severity of abrasion in both groups.

\section{ORCID iDs}

Justyna Oleszek-Listopad(Dhttps://orcid.org/0000-0003-3186-2511 Joanna Rosiak (Dhttps://orcid.org/0000-0002-5570-9813

Jolanta Szymańska@i@ttps://orcid.org/0000-0002-9917-2907

\section{REFERENCES}

1. Łapuć M, Gołębiewska M, Kondrat W. Częstość występowania i diagnostyka dysfunkcji narządu żucia u pacjentów w wieku 20-30 lat. Doniesienie wstępne. Mag Stomatol. 2011;21(2):12-7.

2. Jagucka-Mętel W, Brzeska P, Kijak E, et al. Terapia dysfunkcji układu ruchowego narządu żucia - problem interdyscyplinarny. Przegląd metod posteppowania. Mag Stomatol. 2013;23(1):30-7.

3. Baron S, Walawander T, Baron A, et al. Estetyczno-funkcjonalna rehabilitacja układu ruchowego narządu żucia. Protet Stomatol. 2011; 61(6):459-65.

4. Hryncewicz M, Tropak K. Ubytki niepróchnicowego pochodzenia - abfrakcja, abrazja, atrycja, erozja. Przegląd piśmiennictwa. Nowa Stomatol. 2014;1:46-52.

5. Sierpińska T, Gołębiewska M. Wpływ zaburzeń morfologicznoczynnościowych układu stomatognatycznego na jakość starcia zębów. Protet Stomatol. 2006;56(5):342-5.

6. Głowacka A, Mustafa ZN, Żak E, et al. Wpływ obecności wad zgryzu, leczenia ortodontycznego oraz zaburzeń okluzji na dysfunkcje stawów skroniowo-żuchwowych - przegląd piśmiennictwa. Dental Forum. 2015;43(1):97-102.
7. Knychalska-Karwan Z. Stomatologia geriatryczna. Kraków: Collegium Medicum UJ;1995:41.

8. Barwińska-Płużyńska J, Kochańska B. Ocena występowania ubytków niepróchnicowego pochodzenia u osób w wieku 55-81 lat, badania wstępne. Czas Stomatol. 2007;60(6):357-66.

9. Rodrigues CA, Oliveira Melchior M, Magri LV, et al. Is the masticatory function changed in patients with temporomandibular disorder? Braz Dent J. 2015;26(2):181-5.

10. Yadav S. A Study on prevalence of dental attrition and its relation to factors of age, gender and to the signs of TMJ dysfunction. J Indian Prosthodont Soc. 2011;11(2):98-105.

11. Mickeviciute E, Ausra Baltrusaityte N, Pileicikiene G. The relationship between pathological wear of teeth and temporomandibular joint dysfunction. Stomatologija, Baltic Dental and Maxillofacial J. 2017;19(1): 3-9.

12. Levartovsky S, Matalon S, Sarig R, et al. The association between dental wear and reduced vertical dimension of the face: A morphologic study on human skulls. Arch Oral Biol. 2015;60(1):174-80.

13. Pergamalian A, Rudy TE, Zaki HS, Greco CM. The association between wear facets, bruxism, and severity of facial pain in patients with temporomandibular disorder. J Prosthet Dent. 2003; 90(2):197-200.

14. List $\mathrm{T}$, Jensen RH. Temporomandibular disorders: Old ideas and new concepts. Cephalalgia. 2017;37(7): 692-704.

15. Jonsgara Ch, Hordvika PA, Bergea ME, et al. Sleep bruxism in individuals with and without attrition-type tooth wear: An exploratory matched case-control electromyographic study. J Dent. 2015;43(12):1504-10.

16. Prymas A, Stopa J. Wpływ czynników środowiskowych wewnątrz i zewnątrzpochodnych na powstawanie ubytków niepróchnicowych. Czas Stomatol. 2013;66(2):170-80.

17. Pietruski JK, Pietruska MD. Dysfunkcja narządu żucia - przyczyny, diagnostyka, leczenie. Mag Stomatol. 2013;12:42-8. 